JAKUB OLESZCZAK

https://doi.org/10.33995/wu2020.1.3

\title{
Pasażer jako ubezpieczony w ramach obowiązkowego ubezpieczenia OC posiadaczy pojazdów mechanicznych - konsekwencje wyroku TSUE w sprawie C-648/17 BTA Baltic Insurance Company
}

Wartykule przedstawiono konsekwencje wyroku TSUE w sprawie BTA Baltic Insurance Company. Zgodnie ze wspomnianym orzeczeniem obowiqzkowe ubezpieczenie komunikacyjne OC obejmuje szkodę wyrzqdzonq otwarciem drzwi pojazdu przez pasażera i uderzeniem nimi w inny pojazd stojacy na parkingu. Z treści przywołanego wyroku wynika, że ubezpieczyciel jest zobowiqzany do pokrywania szkód wyrzadzonych przez pasażerów pojazdu. Należy jednak wskazać, że zakład ubezpieczeń będzie zobowiqzany do zapłaty odszkodowania z tytułu umowy ubezpieczenia OC tylko wówczas, gdy ubezpieczonemu zostanie przypisana odpowiedzialność cywilnoprawna za wyrzqdzenie szkody. Zgodnie zaś z polskim prawem ubezpieczonymi w ramach ubezpieczenia komunikacyjnego OC sq wyłacznie posiadacz pojazdu oraz kierujacy nim. Tymczasem istnieja sytuacje, w których w świetle prawa polskiego jedynym odpowiedzialnym za wyrzqdzenie szkody będzie pasażer. W takich wypadkach poszkodowany pozbawiony jest ochrony ubezpieczeniowej, co pozostaje w sprzeczności z przywołanym wyrokiem TSUE. W zwiqzku z powyższym należy postulować zmianę polskiego prawa przez dodanie pasażera do katalogu osób ubezpieczonych w ramach obowiqzkowego ubezpieczenia OC posiadaczy pojazdów mechanicznych.

Słowa kluczowe: ruch pojazdu mechanicznego, obowiązkowe ubezpieczenie OC posiadaczy pojazdów mechanicznych, ubezpieczony, odpowiedzialność cywilnoprawna, odszkodowanie. 


\section{Wprowadzenie}

Obowiązkowe ubezpieczenie komunikacyjne OC zostało uregulowane nie tylko w prawie krajowym, ale też na poziomie unijnym. Podstawowym celem przepisów prawa UE regulujących tę materię jest stworzenie systemu wspólnych zasad chroniących ofiary wypadków drogowych ${ }^{1}$. Zasadnicze znaczenie ma w tym zakresie dyrektywa Parlamentu Europejskiego i Rady 2009/103/WE², która określa podstawowe wymagania dotyczące krajowych regulacji z zakresu ubezpieczeń komunikacyjnych OC. Te unijne wymogi precyzuje Trybunału Sprawiedliwości UE, który w swoich wyrokach dokonuje wykładni prawa unijnego odnoszącego się do tego ubezpieczenia. Jednym z takich orzeczeń jest wyrok z 15 listopada 2018 roku w sprawie C-648/17 BTA Baltic Insurance Company AS v. „Baltijas Apdrošināšanas Nams” AS. W przywołanej sprawie Trybunał Sprawiedliwości UE uznał, że obowiązkowe ubezpieczenie komunikacyjne OC powinno objać sytuację, w której pasażer stojącego na parkingu pojazdu w trakcie otwierania drzwi tego pojazdu uderzył i uszkodził stojacy obok samochód. Przytoczone rozstrzygnięcie prima facie nie budzi kontrowersji. Jednak analiza niektórych szczegółowych kwestii poruszonych w przedmiotowym orzeczeniu prowadzi do wniosku, że prawo polskie zbyt wąsko ujmuje kragg osób, których odpowiedzialność cywilna jest ubezpieczona w ramach obowiązkowego ubezpieczenia komunikacyjnego. W związu z powyższym celem niniejszego artykułu będzie omówienie wskazanego wyroku TSUE i jego konsekwencji, a zwłaszcza odpowiedź na pytanie, czy omawiane orzeczenie powoduje konieczność uznania pasażera za osobę ubezpieczoną w ramach obowiązkowego ubezpieczenia OC posiadaczy pojazdów mechanicznych ${ }^{4}$.

\section{Podstawowe zagadnienia dotyczące odpowiedzialności ubezpieczyciela w ramach obowiązkowego ubezpieczenia OC posiadaczy pojazdów mechanicznych}

Rozważania dotyczące przywołanego orzeczenia TSUE należy poprzedzić przedstawieniem ogólnych zasad dotyczạcych odpowiedzialności ubezpieczyciela w ramach obowiązkowego ubezpieczenia

1. P. Bucoń, Odpowiedzialność cywilna uczestników wypadku komunikacyjnego, Wolters Kluwer, Warszawa 2008, s. 121.

2. Dyrektywa Parlamentu Europejskiego i Rady 2009/103WE z dnia 16 września 2009 r. w sprawie ubezpieczenia od odpowiedzialności cywilnej za szkody powstałe w związku z ruchem pojazdów mechanicznych i egzekwowania obowiązku ubezpieczania od takiej odpowiedzialności (Dz. U. 2009, L 263, s. 11).

3. Wyrok TSUE z 15 listopada 2018 r., C-648/17, „BTA Baltic Insurance Company” AS v. „Baltijas Apdrošināšanas Nams" AS, LEX nr 2595237.

4. Wskazany wyrok TSUE byłjuż komentowany w doktrynie, zob. K. Konieczna, Granice pojęcia „ruchu pojazdów” w rozumieniu prawa Unii Europejskiej dotyczqcego obowiqzkowych ubezpieczeń komunikacyjnych - uwagi na tle orzeczenia Trybunału Sprawiedliwości w sprawie C-648/17 BTA Baltic Insurance Company, „Wiadomości Ubezpieczeniowe" 2018, nr 4. Przywołany artykuł koncentrował się na rozumieniu pojęcia ruchu pojazdu, podczas gdy w niniejszej pracy położono nacisk na analizę konieczności poszerzenia kręgu osób ubezpieczonych w ramach ubezpieczenia obowiązkowego OC posiadaczy pojazdów. 
OC posiadaczy pojazdów mechanicznych. Dopiero na tym tle będzie można określić, jakie znaczenie dla polskiego porządku prawnego ma omawiany wyrok TSUE.

Przedmiotowe ubezpieczenie jest ubezpieczeniem odpowiedzialności cywilnej. Istota tego ubezpieczenia polega na tym, że w sytuacji powstania odpowiedzialności cywilnej objętej zakresem ubezpieczenia po stronie ubezpieczonego zakład ubezpieczeń ma wykonać zobowiązanie ubezpieczonego wobec jego wierzyciela. W ten sposób zakład ubezpieczeń wstępuje w miejsce ubezpieczonego jako dłużnik ${ }^{5}$. Charakterystyczną cechą ubezpieczenia odpowiedzialności cywilnej jest zasada akcesoryjności, która oznacza, przede wszystkim, że odpowiedzialność ubezpieczyciela jest zawisła od odpowiedzialności cywilnej ubezpieczonego ${ }^{6}$. Wskutek tego ubezpieczyciel będzie zobowiązany do zapłaty odszkodowania tylko wówczas, gdy odpowiedzialność cywilna ponosić będzie ubezpieczony, a wysokość odszkodowania, jakie ma zapłacić ubezpieczyciel, nie może być wyższa niż kwota, do zapłaty której jest zobowiązany ubezpieczony? Ponadto, zgodnie z zasadą akcesoryjności, zakład ubezpieczeń będzie mógł podnieść wszelkie zarzuty, jakie przysługują ubezpieczonemu wobec wierzyciela, np. zarzut przyczynienia się poszkodowanego ${ }^{8}$.

Źródłem odpowiedzialności ubezpieczyciela w ramach ubezpieczenia OC jest umowa ubezpieczenia. W przypadku obowiązkowych ubezpieczeń OC prawo nakłada obowiązek zawarcia takiej umowy. Należy jednak zaznaczyć, że znaczna część postawień umów obowiązkowego ubezpieczenia OC jest zdeterminowana treścią aktów prawnych, które najczęściej nie dają stronom możliwości swobodnego kształtowania stosunku umownego. Powodem tego jest fakt, że ustawodawca, wprowadzając obowiązkowe ubezpieczenie OC w określonej dziedzinie, pragnie dojść do pewnego wspólnego poziomu ochrony ubezpieczeniowej wszystkich ubezpieczonych ${ }^{9}$. W przypadku obowiązkowego ubezpieczenia OC posiadaczy pojazdów mechanicznych aktem prawnym regulującym większość istotnych kwestii jest ustawa z dnia 22 maja 2013 roku o ubezpieczeniach obowiązkowych, Ubezpieczeniowym Funduszu Gwarancyjnym i Polskim Biurze Ubezpieczycieli Komunikacyjnych ${ }^{10}$.

Spośród przepisów wspomnianej ustawy podstawowe znaczenie dla określenia zasad odpowiedzialności ubezpieczyciela mają art. 34 i 35 u.u. ${ }^{11}$. Zgodnie z art. 34 ust. 1 u.u.o. z ubezpieczenia OC posiadaczy pojazdów mechanicznych przysługuje odszkodowanie, jeżeli posiadacz lub kierujący pojazdem mechanicznym są obowiązani do odszkodowania za wyrządzoną w związku z ruchem tego pojazdu szkodę, będącą następstwem śmierci, uszkodzenia ciała, rozstroju zdrowia bądź też utraty, zniszczenia lub uszkodzenia mienia. Natomiast według ust. 2 przywołanego

5. Sz. Byczko, B. Kucharski, [w:] Prawo gospodarcze i handlowe, [red.] W. Katner, Wolters Kluwer, Warszawa 2018, s. 664.

6. J. Pokrzywniak, [w:] M. Orlicki, J. Pokrzywniak, A. Raczyński, Obowiqzkowe ubezpieczenie OC posiadaczy pojazdów mechanicznych, Oficyna Wydawnicza Branta, Bydgoszcz-Poznań 2007, s. 50-52.

7. Ibidem.

8. S. Byczko, B. Kucharski, [w:] Prawo gospodarcze ..., s. 665. Należy jednak wskazać, że aktualne orzecznictwo Sądu Najwyższego nieco osłabia zasadę akcesoryjności. Przejawem tego jest wyrok SN z 30 maja 2014 r., sygn. III CSK 224/13, LEX nr 1504840. W przywołanym wyroku SN stwierdził, że zasada akcesoryjności ogranicza się wyłącznie do momentu powstania zobowiązania i zwolnienie z długu ubezpieczonego przez poszkodowanego nie prowadzi do wygaśnięcia roszczenia poszkodowanego wobec ubezpieczyciela.

9. S. Byczko, Prawo ubezpieczeń gospodarczych. Zarys wykładu, Difin, Warszawa 2013, s. 196.

10. Tekst jedn. Dz. U. 2018, poz. 473; dalej: u.u.o.

11. G. Bieniek, Odpowiedzialność cywilna za wypadki drogowe, Wolters Kluwer, Warszawa 2007, s. 69. 
przepisu za szkodę powstałą w związku z ruchem pojazdu mechanicznego uważa się również szkodę powstała podczas i w związku z: wsiadaniem do pojazdu mechanicznego lub wysiadaniem z niego, bezpośrednim załadowywaniem lub rozładowywaniem pojazdu mechanicznego oraz zatrzymaniem lub postojem pojazdu mechanicznego. Z kolei w myśl art. 35 u.u.o. ubezpieczeniem OC posiadaczy pojazdów mechanicznych jest objęta odpowiedzialność cywilna każdej osoby, która kierując pojazdem mechanicznym w okresie trwania odpowiedzialności ubezpieczeniowej, wyrządziła szkodę w związku z ruchem tego pojazdu.

Jak wynika z powyższych przepisów, aby przypisać odpowiedzialność ubezpieczycielowi z tytułu obowiązkowego ubezpieczenia OC, wymagane jest spełnienie przesłanek, które są wspólne dla powstania każdego rodzaju odpowiedzialności w prawie polskim. Są nimi: zdarzenie objęte odpowiedzialnością cywilna, czyli w omawianym przypadku ruch pojazdu mechanicznego, szkoda oraz związek przyczynowy między tym zdarzeniem a szkodą ${ }^{12}$. Spośród zaś wymienionych przesłanek, zasadnicze znaczenie dla określenia odpowiedzialności ubezpieczyciela w ramach ubezpieczenia komunikacyjnego $\mathrm{OC}$ ma ruch pojazdu mechanicznego ${ }^{13}$. To pojęcie, w ocenie większości przedstawicieli piśmiennictwa, ma szerszy zakres od „ruchu mechanicznego środka komunikacji poruszanego za pomoca sił przyrody" z art. 436 k.c. ${ }^{14}$, bowiem art. 34 ust. 2 u.u.o. rozszerza zakres ruchu pojazdu na sytuacje, które trudno uznać za ruch w rozumieniu art. 436 k.c., takie jak choćby postój. Nie wchodząc w szczegółowe rozważania dotyczące relacji tych pojęć, należy stwierdzić, że ubezpieczyciel będzie zobowiązany do naprawienia szkody w dwóch przypadkach. Pierwszym z nich jest sytuacja, gdy ubezpieczony posiadacz będzie ponosił odpowiedzialność na zasadzie ryzyka za ruch mechanicznego środka komunikacji, zgodnie z art. 436 k.c. Drugim z nich zaś jest przypadek, gdy ubezpieczony będzie odpowiadał na zasadzie winy - jeśli szkoda zostanie wyrządzona przez ruch pojazdu, który nie zostanie uznany za ruch w rozumieniu art. 436 § 1 k.c., jak i w wypadkach określonych w art. 436 § 2 k.c. - tj. przy zderzeniu się pojazdów oraz wyrządzeniu szkód osobom przewożonym z grzeczności. Ochroną ubezpieczeniowa jest też objęta odpowiedzialność cywilna kierujaccego nie będącego posiadaczem, który zawsze odpowiada na zasadzie winy ${ }^{15}$.

Oprócz spełnienia wymienionych wyżej przesłanek dla przypisania odpowiedzialności ubezpieczycielowi konieczne jest, jak już wskazano powyżej, uprzednie stwierdzenie odpowiedzialności posiadacza lub kierującego pojazdem. Jest to przejaw wspominanej wcześniej zasady akcesoryjności. W doktrynie podkreśla się, że ta reguła prowadzi do bardzo szerokiego ujęcia zakresu odpowiedzialności ubezpieczyciela ${ }^{16}$. Dowodem tego jest art. 9 ust. 2 u.u.o., zgodnie z którym zakład

12. A. Raczyński, Sytuacja prawna poszkodowanego w ubezpieczeniu odpowiedzialności cywilnej, CH Beck, Warszawa 2010, s. 46-47.

13. K. Niezgoda, [w:] J. Miaskowski, K. Niezgoda, P. Skawiński, Ustawa o ubezpieczeniach obowiqzkowych, Ubezpieczeniowym Funduszu Gwarancyjnym i Polskim Biurze Ubezpieczycieli Komunikacyjnych, CH Beck, Warszawa 2012, s. 188.

14. M. Krajewski, Ubezpieczenie odpowiedzialności cywilnej według kodeksu cywilnego, Wolters Kluwer, Warszawa 2011, s. 112; J. Szczechowicz, Odpowiedzialność cy wilna posiadacza mechanicznego środka komunikacji za szkody wyrzqdzone w ruchu lqdowym, Pracownia Wydawnicza ElSet, Olsztyn 2013, s. 22-23; P. Bucoń, op. cit., s. 57; K. Niezgoda, op. cit., s. 189.

15. A. Wạsiewicz, Ubezpieczenia komunikacyjne, Oficyna Wydawnicza Branta, Bydgoszcz-Poznań 2001, s. 69.

16. K. Ludwichowska, Odpowiedzialność cywilna i ubezpieczeniowa za wypadki samochodowe, TNOiK, Toruń 2008, s. 304-305. 
ubezpieczeń jest odpowiedzialny również za szkody wyrządzone umyślnie lub w wyniku rażącego niedbalstwa ubezpieczającego lub osób, za które ponosi on odpowiedzialność. Tylko w przypadku wyrządzenia szkody umyślnie ubezpieczyciel będzie mógł domagać się zwrotu wypłaconego świadczenia ${ }^{17}$. Ustalenie szerokiego zakresu odpowiedzialności zakładu ubezpieczeń ma służyć przede wszystkim poszkodowanym, chroni jednak także ubezpieczonego przed ponoszeniem odpowiedzialności cywilnej, nawet w sytuacji, gdy wykazałby się rażącym niedbalstwem ${ }^{18}$.

Jednak z drugiej strony, wskazanie, że ubezpieczonymi w ramach przedmiotowego ubezpieczenia są wyłącznie posiadacz pojazdu oraz kierujący nim, w oczywisty sposób ogranicza zakres odpowiedzialności ubezpieczyciela. Należy bowiem stwierdzić, że niekiedy za wyrządzona przez ruch pojazdu szkodę będzie odpowiedzialny podmiot, który nie jest ani posiadaczem pojazdu, ani kierującym nim. Ze względu na szeroki zakres odpowiedzialności cywilnej posiadacza pojazdu, jaki wynika z art. 436 k.c., nie są to przypadki liczne. Niemniej jednak nie można takiej sytuacji wykluczyć. Właśnie taki problem został podjęty przez TSUE w wyroku w sprawie BTA Baltic Insurance.

\section{Sprawa BTA Baltic Insurance - stan faktyczny}

Kanwą dla omawianego orzeczenia TSUE był wypadek, do jakiego doszło na parkingu supermarketu na Łotwie. Pasażer jednego z samochodów, otwierając drzwi pojazdu, uderzył nimi w inny pojazd stojący obok. Na miejscu zdarzenia wypełniono oświadczenie, w którym kierowca samochodu, którego pasażerem był sprawca szkody, przyznał się do winy. Właścicielowi uszkodzonego pojazdu odszkodowanie wypłacił zakład ubezpieczeń, z którym miał zawartą umowę ubezpieczenia autocasco. Następnie wspomniany ubezpieczyciel zwrócił się o zwrot wypłaconego odszkodowania do zakładu ubezpieczeń, z którym zawarto umowę ubezpieczenia OC dotycząca pojazdu, którego pasażer doprowadził do powstania szkody. Ten jednak odmówił spełnienia żądania, argumentując, że przedmiotowy wypadek nie jest objęty zakresem obowiązkowego ubezpieczenia komunikacyjnego OC. Opisana sprawa trafiła do sądu. Łotewski sąd odwoławczy uznał, że omawiane zdarzenie nie jest objęte zakresem obowiązkowego ubezpieczenia OC, ponieważ żaden z uczestniczących w wypadku samochodów nie znajdował się w ruchu. Ponadto sąd stwierdził, że odpowiedzialności cywilnej za spowodowanie szkód w drugim pojeździe nie ponosi kierowca pierwszego pojazdu, lecz jego pasażer, zgodnie zaś z łotewską ustawa przedmiotem obowiązkowego ubezpieczenia jest odpowiedzialność cywilna wyłącznie właściciela pojazdu lub jego uprawnionego użytkownika. Od tego wyroku wniesiono skargę do Augstākā tiesa ${ }^{19}$. Sąd ten postanowił wystapić z wnioskiem o wydanie orzeczenia w trybie prejudycjalnym do TSUE i zadał dwa pytania:

Czy art. 3 ust. 1 pierwszej dyrektywy ${ }^{20}$ należy interpretować w ten sposób, że w zakres pojęcia „ruchu pojazdów” wchodzi sytuacja taka, jak ta będąca przedmiotem sporu, czyli otwarcie drzwi pojazdu podczas postoju?

17. K. Niezgoda, op. cit., Warszawa 2012, s. 76.

18. K. Ludwichowska, op. cit., s. 305.

19. Sąd Najwyższy na Łotwie.

20. Dyrektywa Rady 72/166/EWG z dnia 24 kwietnia 1972 r. w sprawie zbliżenia ustawodawstw państw członkowskich odnoszących się do ubezpieczenia od odpowiedzialności cywilnej za szkody powstałe w związku z ruchem pojazdów mechanicznych i egzekwowania obowiązku ubezpieczania od takiej odpowiedzialności 
Czy art. 3 ust. 1 pierwszej dyrektywy należy interpretować w ten sposób, że w zakres pojęcia „ruchu pojazdów” wchodzi sytuacja taka, jak ta będąca przedmiotem sporu, czyli sytuacja, w której szkoda na mieniu osoby trzeciej powstaje w wyniku użytkowania pojazdu przez pasażera?

Tak zadane pytania wyznaczają dwa zagadnienia, którymi musiał zajać się Trybunał Sprawiedliwości UE. Pierwsze z nich dotyczy interpretacji pojęcia ruchu pojazdu. Nie budzi ono większych kontrowersji. W polskim orzecznictwie i doktrynie nie ma wạtpliwości, że ruch pojazdu, tak w rozumieniu art. 436 k.c., jak i 34 u.u.o. obejmuje sytuacje otwierania i zamykania drzwi pojazdu ${ }^{21}$. Znacznie ciekawsze jest natomiast pytanie drugie. Tylko pozornie dotyczy ono również wykładni pojęcia ruchu pojazdu. W istocie bowiem sprowadza się do tego, czy obowiązkowe ubezpieczenie komunikacyjne OC powinno dotyczyć także odpowiedzialności cywilnej pasażera. Temu zagadnieniu będa głównie poświęcone dalsze rozważania.

\section{Stanowisko rządu polskiego w sprawie BTA Baltic Insurance}

W postępowaniu prejudycjalnym w sprawie BTA Baltic Insurance swoje uwagi na piśmie przedstawił rząd polski ${ }^{22}$. Warto poddać to stanowisko analizie, gdyż w swoim wyroku TSUE krytycznie odniesie się do przedstawionych przez rząd polski opinii. W odniesieniu do pierwszego z pytań zadanych przez łotewski sąd rząd polski wyraził ocenę, że zdarzenie będące przedmiotem postępowania powinno być objęte zakresem pojęcia ruchu pojazdu. Rząd polski, uzasadniając swoje stanowisko, przywołał zarówno wcześniejsze wyroki TSUE dotyczące ruchu pojazdu²3, jak i orzeczenia polskiego Sadu Najwyższego wydane w analogicznych sprawach ${ }^{24}$. Jednak większość uwagi rząd polski poświęcił odpowiedzi na pytanie drugie. W pierwszej kolejności zaznaczył, opierając się na wcześniejszych orzeczeniach TSUE ${ }^{25}$, że prawo unijne tyczy się wyłącznie kwestii ubezpieczenia odpowiedzialności cywilnej związanej z ruchem pojazdów mechanicznych, a nie zagadnienia odpowiedzialności cywilnoprawnej za wypadki drogowe. Rząd podnosił, że państwa członkowskie mają swobodę stanowienia zasad odpowiedzialności cywilnej za szkody komunikacyjne,

(Dz. U. 1972, L 103, s. 1). Obecnie zastapiona dyrektywą Parlamentu Europejskiego i Rady 2009/103WE. Istotne dla niniejszej pracy przepisy nie uległy zmianie, stad ustalenia TSUE poczynione na gruncie pierwszej dyrektywy ubezpieczeniowej zachowują swoją aktualność.

21. G. Bieniek, [w:] Kodeks cywilny. Tom III. Zobowiqzania. Część ogólna, [red.] J. Gudowski, Wolters Kluwer, Warszawa 2018, s. 888-889; M. Zelek, [w:] Kodeks cywilny. Tom II. Komentarz art. 353-626, [red.] M. Gutowski, CH Beck, Warszawa 2019, s. 769-770; W. Dubis, [w:] Kodeks cywilny. Komentarz, [red.] E. Gniewek, P. Machnikowski, CH Beck, Warszawa 2019, s. 961.

22. Uwagi na piśmie Rzeczpospolitej Polskiej przedkładane na podstawie art. 23 Statutu Trybunału Sprawiedliwości w postępowaniu o wydanie orzeczenia wstępnego w sprawie C-648/17 Balcia Insurance - dokument uzyskany przez autora od Ministerstwa Spraw Zagranicznych w ramach udzielenia informacji publicznej.

23. Wyrok TSUE z 4 września 2014 r., C-162/13, Damijan Vnuk v. Zavarovalnica Triglav d.d., LEX nr 1500724; wyrok TSUE z 28 listopada 2017 r., C 514/16, Isabel Maria Pinheiro Vieira Rodrigues de Andrade i Fausto da Silva Rodrigues de Andrade v. José Manuel Proença Salvador i in., LEX nr 2399695.

24. Wyrok SN z 14 kwietnia 1975 r., sygn. II CR 114/75, LEX nr 1883; wyrok SN z 11 kwietnia 2003 r., sygn. III CKN 1522/00, LEX nr 146430.

25. Wyrok TSUE z 7 września 2017 r., C-506/16, José Joaquim Neto de Sousa v. Estado português, LEX nr 2349995; wyrok TSUE z 23 października 2012 r., C-300/10, Vítor Hugo Marques Almeida v. Companhia de Seguros Fidelidade-Mundial SA i in., LEX nr 1222348. 
a przewidywane w ustawodawstwach krajowych ograniczenia tej odpowiedzialności sa dopuszczalne, o ile tylko nie pozbawią one skuteczności (effet utile) unijnych regulacji dotyczących obowiązkowego ubezpieczenia komunikacyjnego OC. Tymczasem, w ocenie polskiego rzadu, drugie z zadanych pytań prejudycjalnych dotyczy właśnie zakresu odpowiedzialności cywilnej za szkody wyrządzone przez ruch pojazdu, zatem kwestii nieobjętej harmonizacją na poziomie UE. Jak bowiem argumentował polski rząd, odpowiedzialność ubezpieczyciela zależy od istnienia odpowiedzialności cywilnoprawnej posiadacza pojazdu lub kierującego nim. W związku z tym, jeśli pytanie dotyczy tego, czy odpowiedzialność zakładu ubezpieczeń obejmuje otwieranie drzwi przez pasażera, to jest to de facto pytanie o to, jaki jest zakres odpowiedzialności cywilnej posiadacza lub kierującego pojazdem. Według polskiego rządu gdyby w Polsce doszło do omawianego zdarzenia, to prawdopodobnie posiadacz samochodu mógłby zwolnić się z odpowiedzialności, wykazując, że szkoda powstała wyłącznie z winy osoby trzeciej, za którą nie ponosi on odpowiedzialności, czyli pasażera. To z kolei wyłączyłoby odpowiedzialność ubezpieczyciela z tytułu obowiązkowego ubezpieczenia OC posiadaczy pojazdów mechanicznych. W związku z tym rząd polski na drugie pytanie prejudycjalne postulował odpowiedź, zgodnie z która prawo unijne nie sprzeciwia się przepisom krajowym wyłączającym odpowiedzialność cywilną ubezpieczonego za szkodę powstała w wyniku użytkowania pojazdu, gdy szkoda powstała wyłącznie z winy pasażera.

\section{Wyrok TSUE w sprawie BTA Baltic Insurance}

Trybunał Sprawiedliwości UE rozpoznał oba pytania łącznie i uznał, że zakresem pojęcia ruchu pojazdów jest objęta sytuacja, w której pasażer stojącego na parkingu pojazdu, przy otwieraniu drzwi tego pojazdu, uderzyłi uszkodził stojący obok pojazd. Uzasadniając swoje stanowisko, TSUE przywołał szereg wcześniejszych wyroków ${ }^{26}$, w których przesądził, że ruch pojazdu obejmuje każde wykorzystanie pojazdu w charakterze środka transportu, niezależnie od tego, gdzie pojazd się znajduje i czy ma włączony silnik. Te rozważania nie budzą wạtpliwości. Należy jednak dokładnie przeanalizować wyjaśnienia Trybunału dotyczące tego, czy zakresem ubezpieczenia są objęte szkody wyrządzone przez pasażera. W tym względzie Trybunał wskazał, że art. 3 pierwszej dyrektywy stanowi jedynie ogólnie, że ubezpieczeniem powinna być objęta „odpowiedzialność cywilna odnosząca się do ruchu pojazdów normalnie przebywających na jego terytorium [każdego państwa członkowskiego]”. Stąd Trybunał wywiódł, że „w przeciwieństwie do stanowiska przedstawionego przez rząd polski w przedmiocie odpowiedzi na pytanie drugie, ani ten przepis, ani inne przepisy dyrektyw dotyczących obowiązkowego ubezpieczenia nie ograniczają zakresu obowiązkowego ubezpieczenia od odpowiedzialności cywilnej do określonej kategorii osób, takich jak kierowca pojazdu". Wydaje się, że jest to kluczowy punkt omawianego uzasadnienia. Trybunał nie przychylił się do stanowiska rządu polskiego, gdyż ten apriorycznie uznał, że ubezpieczenie komunikacyjne OC obejmuje szkody, za które odpowiedzialność cywilna ponoszą jedynie posiadacz i kierujący pojazdem. Przy takim założeniu odpowiedź na drugie pytanie prejudycjalne rzeczywiście musiałaby sprowadzać się do problemu zakresu odpowiedzialności cywilnoprawnej posiadacza pojazdu,

26. Wyrok TSUE z 4 września 2014 r., C-162/13, Damijan Vnuk v. Zavarovalnica Triglav d.d., LEX nr 1500724; wyrok TSUE z 28 listopada 2017 r., C 514/16, Isabel Maria Pinheiro Vieira Rodrigues de Andrade i Fausto da Silva Rodrigues de Andrade v. José Manuel Proença Salvador i in., LEX nr 2399695. 
która, co do zasady, nie jest objęta harmonizacją unijną. Tymczasem Trybunał wskazuje, że prawo unijne nie określa kręgu podmiotów ubezpieczonych w ramach ubezpieczenia komunikacyjnego OC, nie można zatem twierdzić, że zakres tego ubezpieczenia obejmuje jedynie odpowiedzialność cywilnoprawna posiadacza i kierującego pojazdem.

Skoro zatem prawo UE nie przewiduje wprost katalogu osób, których odpowiedzialność cywilna za szkody wyrządzone w związku z ruchem pojazdu jest ubezpieczona, należy rozważyć, czy taką osoba jest pasażer. Trybunał Sprawiedliwości na to pytanie odpowiada twierdzaco. W jego ocenie przedmiotowe ubezpieczenie odnosi się do odpowiedzialności cywilnej wynikającej nie tylko z kierowania pojazdami, ale też z korzystania z samochodu przez osoby, które nie są kierowcami. Trybunał powołuje się także na swoje wcześniejsze orzeczenie ${ }^{27}$, w którym stwierdził, że odpowiedzialność ubezpieczyciela nie może być wyłączona w przypadku, gdy wypadek spowodowała inna osoba niż wskazana w polisie ubezpieczeniowej. Ponadto w omawianym wyroku wskazano, że wchodzenie i wychodzenie z samochodu przez pasażerów to użytkowanie pojazdu zgodnie z jego funkcją transportową, zatem objęte pojęciem ruchu pojazdów. W konsekwencji Trybunał uznał, że „okoliczność, iż rozpatrywany w postępowaniu głównym wypadek nie jest spowodowany działaniem kierowcy pierwszego pojazdu, tylko jego pasażera, nie wyklucza sam w sobie, że użytkowanie tego pojazdu w takiej chwili może odpowiadać jego funkcji środka transportu, a w konsekwencji być objęte zakresem pojęcia ruchu pojazdów w rozumieniu art. 3 ust. 1 pierwszej dyrektywy".

\section{Pasażer jako ubezpieczony w ramach obowiązkowego ubezpieczenia komunikacyjnego OC - konsekwencje wyroku TSUE}

W tym miejscu należy zastanowić się, jakie konsekwencje wywołuje omawiany wyrok dla polskiego porządku prawnego. Z pozoru mogłoby się zdawać, że nie wnosi on wiele nowego dla określenia zasad odpowiedzialności ubezpieczyciela z tytułu obowiązkowego ubezpieczenia OC posiadaczy pojazdów. Gdyby bowiem zdarzenie, będące kanwą dla niniejszej sprawy, wydarzyło się w Polsce, wówczas ubezpieczyciel byłby zobowiązany do zapłaty odszkodowania. Tak jak wcześniej wskazano, czynność wychodzenia z samochodu i otwierania drzwi jest objęta pojęciem ruchu mechanicznego środka komunikacji w rozumieniu art. 436 § 1 k.c. Za szkodę wyrządzona przez pasażera odpowiada więc posiadacz samoistny lub zależny pojazdu. Należy stwierdzić, wbrew przywołanemu stanowisku rządu polskiego, że posiadacz nie mógłby zwolnić się od odpowiedzialności, twierdząc, że szkoda powstała wyłącznie z winy osoby trzeciej, za którą nie ponosi on odpowiedzialności. Jak wskazuje bowiem przeważająca część przedstawicieli piśmiennictwa, nie można uznać za „osobę trzecią, za która posiadacz nie ponosi odpowiedzialności” osoby podróżującej autem - ani kierowcy, ani pasażera ${ }^{28}$. Zgodnie z przyjętym przez większość doktryny poglądem

27. Wyrok TSUE z 1 grudnia 2011 r., C-442/10, Churchill Insurance Company Limited v. Benjamin Wilkinson and Tracy Evans v. Equity Claims Limited, LEX nr 105340 ?

28. M. Wałachowska, Michał P. Ziemiak, [w:] Kodeks cywilny. Komentarz. Tom III. Zobowiqzania. Część ogólna, [red.] M. Habdas, M. Fras, Wolters Kluwer, Warszawa 2018, s. 565; A. Śmieja, Odpowiedzialność za ruch pojazdu mechanicznego, [w:] System Prawa Prywatnego. Tom 6. Prawo zobowiqzań - część ogólna, [red.] A. Olejniczak, CH Beck, Warszawa 2014, s. 633; A. Olejniczak, [w:] Kodeks cywilny. Komentarz LEX, [red.] A. Kidyba, Warszawa 2014, s. 514. Odmiennie: M. Zelek, [w:] Kodeks cywilny. Tom II. Komentarz art. 353-626 ..., s. 774. 
odnoszącym się do odpowiedzialności za szkody wyrządzone ruchem przedsiębiorstwa, osoba trzecia nie może być w jakikolwiek sposób włączona w ruch przedsiębiorstwa. Musi być osobą obca wobec prowadzącego przedsiębiorstwo i ruchu przedsiębiorstwa ${ }^{29}$. Przytoczoną opinię można odnieść do ruchu mechanicznego środka komunikacji. Zatem: by posiadacz pojazdu mógł zwolnić się z odpowiedzialności, musiałby wykazać, że szkoda powstała wyłącznie z winy osoby, która nie jest włączona w ruch pojazdu. Za taką nie można zaś uznać pasażera, który podróżuje w samochodzie, a otwierając drzwi, niejako bezpośrednio „uczestniczy w ruchu”. Należy zatem stwierdzić, że posiadacz mechanicznego środka komunikacji będzie ponosił odpowiedzialność cywilnoprawną za szkodę, jaką wyrządzi pasażer wysiadający z pojazdu i uderzający drzwiami w inny, stojący obok samochód. Skoro tak, to do zapłaty odszkodowania będzie zobowiązany także zakład ubezpieczeń. Jak wskazano bowiem wcześniej, odpowiedzialność ubezpieczyciela z tytułu obowiązkowego ubezpieczenia OC posiadaczy pojazdów mechanicznych zależy od odpowiedzialności cywilnoprawnej ubezpieczonych - posiadacza pojazdu i kierującego nim. W takiej sytuacji zatem prawo polskie spełnia wymogi stawiane przez Trybunał Sprawiedliwości UE.

Wystarczy jednak nieco zmodyfikować stan faktyczny będący kanwą dla omawianej sprawy, by stwierdzić, że polskie ustawodawstwo nie zawsze będzie realizowało wymagania nałożone przez unijne prawo. Można sobie bowiem wyobrazić następujący wypadek: pasażer, chcąc wysiaść z zaparkowanego samochodu, otwiera drzwi i uderza nimi o otwarte drzwi pojazdu stojacego obok, do którego właśnie wchodzi jego kierowca. W takiej sytuacji dochodzi do zderzenia się dwóch mechanicznych środków komunikacji w rozumieniu art. 436 § 2 k.c. Zderzeniem jest bowiem każde fizyczne zetknięcie się pojazdów będących w ruchu w rozumieniu art. 436 k.c. ${ }^{30}$ Nie ulega przy tym wạtpliwości, że wsiadanie i wysiadanie z pojazdu jest przejawem ruchu mechanicznego środka komunikacji. W takiej sytuacji zatem odpowiedzialność posiadacza pojazdu, z którego wychodził pasażer, będzie ukształtowana nie na zasadzie ryzyka, lecz winy. Trudno zaś obarczać wina posiadacza czy kierującego pojazdem w sytuacji nieostrożnego wysiadania z zaparkowanego auta przez pasażera. Zatem w takim stanie faktycznym jedyna osobą, która ponosi odpowiedzialność za wyrządzoną szkodę jest pasażer. Natomiast zakres odpowiedzialności ubezpieczeniowej ogranicza się wyłącznie do odpowiedzialności cywilnej posiadacza pojazdu i kierującego nim. Stąd, w świetle obecnie obowiązujących w Polsce regulacji, za taką szkodę nie będzie ponosił odpowiedzialności ubezpieczyciel z tytułu obowiązkowego ubezpieczenia OC posiadaczy pojazdów mechanicznych. To zaś sprawia, że polskie prawo nie realizuje w pełni wymogów określonych przez TSUE w wyroku w sprawie BTA Baltic Insurance. Do takiej sytuacji może dojść wtedy, gdy posiadacz pojazdu będzie ponosił odpowiedzialność cywilną na zasadzie winy, a nie ryzyka, tj. w wypadkach określonych w art. 436 § 2 k.c. Wówczas bowiem możliwe jest przypisanie odpowiedzialności za szkodę wyłącznie pasażerowi.

Do szkód wyrządzonych przez otworzenie drzwi samochodu przez pasażera może dochodzić nie tylko na parkingu. Dowodzi tego wypadek, będący kanwą dla wyroku Sądu Rejonowego

29. B. Lewaszkiewicz-Petrykowska, Odpowiedzialność cywilna prowadzqcego na własny rachunek przedsiębiorstwo wprawiane w ruch za pomoca sił przyrody, Wydawnictwo Prawnicze, Łódź 1965, s. 9?.

30. A. Śmieja, op. cit., s. 609; W. Robaczyński, Kontrowersje wokół pojęcia ruchu pojazdu (art. 436 k.c.), „Palestra” 2007, nr 5-6. Odmiennie: wyrok SN z 5 lutego 2002 r., sygn. V CKN 644/00, LEX nr 56410. 
Poznań-Stare Miasto w Poznaniu ${ }^{31}$. Stan faktyczny w tej sprawie był następujący: taksówkarz zatrzymał się na chodniku, wbrew zakazowi zatrzymania i postoju, w celu wysadzenia przewożonej osoby. Pasażerka taksówki, wysiadając od strony ulicy uderzyła drzwiami pojazdu w inny samochód, który przejeżdżał ulica. W tej sprawie ubezpieczyciel, z którym posiadacz taksówki zawarł umowę ubezpieczenia obowiązkowego OC, argumentował, że doszło do zderzenia dwóch pojazdów będących w ruchu, zatem posiadacze pojazdów odpowiadają względem siebie na zasadzie winy. Za powstała szkodę, w ocenie ubezpieczyciela, ponosi odpowiedzialność wyłącznie pasażerka, która zbyt szeroko otworzyła drzwi samochodu. Stąd ubezpieczyciel nie jest zobowiązany do naprawienia wyrządzonej szkody, gdyż ubezpieczony (posiadacz, kierujący) nie ponosi odpowiedzialności cywilnoprawnej za wypadek.

Sąd rozpoznający niniejszą sprawę przyznał, że doszło do zderzenia dwóch mechanicznych środków komunikacji w rozumieniu art. 436 § 2 k.c. Jednak zdaniem sadu taksówkarz ponosił winę za wyrządzoną szkodę, ponieważ jako profesjonalista powinien zachować szczególną ostrożność i zapewnić odpowiednie bezpieczeństwo pasażerom podczas całej trasy. Tymczasem w ocenie sądu taksówkarz nie sprawdził, czy pasażerka może bezpiecznie wyjść z samochodu. Konsekwencją zaś przypisania odpowiedzialności ubezpieczonemu kierującemu jest obowiązek pokrycia szkody przez zakład ubezpieczeń.

W przywołanej sprawie zatem ubezpieczyciel został zobowiązany do naprawienia szkody, gdyż przypisano winę ubezpieczonemu kierującemu. Jednak nietrudno przestawić podobną sytuację, gdy winą można obciążyć wyłącznie wychodzạcego z samochodu pasażera. Kierujący nie zawsze jest bowiem profesjonalistą, zatem stawiane mu wymagania w zakresie należytej staranności będą miały inny charakter. Można nawet wyobrazić sobie, że pasażer postępuje wbrew zakazowi kierującego i wysiada z pojazdu, doprowadzając do uderzenia drzwiami o jadący samochód. W takim wypadku winę ponosiłby wyłącznie nieostrożny pasażer.

Wskazane powyżej przykłady dowodzą, że pasażer, otwierając drzwi pojazdu, może wyrządzić innym uczestnikom ruchu szkodę, za którą będzie wyłącznie odpowiedzialny. Jak wskazano powyżej, w takich sytuacjach, w myśl prawa polskiego, nie będzie zobowiązany do naprawienia szkody ubezpieczyciel z tytułu obowiązkowego ubezpieczenia OC posiadaczy pojazdów mechanicznych. Jednak takie ograniczenie odpowiedzialności ubezpieczyciela nie spełnia wymagań stawianych regulacjom dotyczącym obowiązkowych ubezpieczeń komunikacyjnych OC przez TSUE w wyroku w sprawie BTA Baltic Insurance.

Odpowiedzialność cywilna pasażera za wypadki drogowe nie ogranicza się wyłącznie do szkód wyrządzonych przez otwarcie drzwi pojazdu. Wydaje się, że zgodnie z omawianym wyrokiem TSUE, także inne szkody, za które ponosi odpowiedzialność pasażer, winny być kompensowane w ramach obowiązkowego ubezpieczenia komunikacyjnego OC. Wprawdzie Trybunał wypowiadał się w konkretnej sprawie, w której doszło do wyrządzenia szkody poprzez otwarcie drzwi pojazdu, jednak w uzasadnieniu orzeczenia TSUE wskazał ogólnie, że fakt, iż to pasażer jest odpowiedzialny za wyrządzona szkodę, nie stoi na przeszkodzie, by obciążyć obowiązkiem naprawienia szkody ubezpieczyciela z tytułu obowiązkowego ubezpieczenia komunikacyjnego OC, pod warunkiem, że w chwili wyrzadzenia szkody pojazd znajdował się w ruchu w rozumieniu prawa UE. Zatem, zgodnie z omawianym wyrokiem TSUE, zakresem obowiązkowego ubezpieczenia OC posiadaczy

31. Wyrok Sądu Rejonowego Poznań-Stare Miasto w Poznaniu z 19 czerwca 2019 r., sygn. IC 1221/18, LEX nr 2694979. 
pojazdów mechanicznych powinna być objęta odpowiedzialność cywilna pasażera, jeżeli jest on odpowiedzialny za szkodę wyrządzona przez ruch pojazdu, przy czym szkoda nie musi być spowodowana tylko otwieraniem drzwi pojazdu.

Przykładem doprowadzenia przez pasażera do wypadku drogowego, w którym szkoda nie została wyrządzona przez otwarcie drzwi pojazdu, może być sprawa zakończona wyrokiem Sądu Najwyższego z 13 sierpnia 2008 roku $^{32}$. Stan faktyczny w tej sprawie był następujący: pasażer samochodu w czasie jazdy gwałtownie szarpnałł za kierownicę, zmieniając tor ruchu pojazdu i doprowadzając do wypadku. W wyniku zdarzenia zginął pasażer - sprawca wypadku oraz inna pasażerka, pozostali podróżujący zaś zostali poważnie ranni. Wszyscy podróżni byli nietrzeźwi, a przed jazdą pili wspólnie alkohol. Matka zmarłej pasażerki wystapiła z roszczeniem do ubezpieczyciela z tytułu obowiązkowego ubezpieczenia OC posiadaczy pojazdów mechanicznych. Sąy obu instancji odmówiły racji powódce, dlatego wystapiła ona ze skarga kasacyjna.

Są Najwyższy w przywołanej sprawie przyjął, że zmarła pasażerka była przewożona z grzeczności. W związku z tym posiadacz mechanicznego środka komunikacji odpowiada za wyrządzona jej szkodę wyłącznie na zasadzie winy. Ponadto Sąd Najwyższy ustalił, że za spowodowanie wypadku odpowiedzialny był wyłącznie pasażer, który szarpnałł za kierownicę. W związku z tym, aby ubezpieczyciel był zobowiązany do naprawienia szkody wyrządzonej ruchem pojazdu, pasażer sprawca wypadku musiałby być posiadaczem pojazdu lub kierującym pojazdem, gdyż wyłącznie te podmioty są ubezpieczone w ramach obowiązkowego ubezpieczenia OC posiadaczy pojazdów mechanicznych. Sąd Najwyższy nie miał wạtpliwości, że pasażer nie był posiadaczem tego pojazdu. Nie uznał go także za „kierującego” w rozumieniu art. 34 u.u.o. Uzasadniając taką ocenę, SN stwierdził, że kierującym jest osoba, która prowadzi pojazd, decyduje o jego ruchu, zatrzymaniu, prędkości. Zdaniem SN pasażer, nawet jeśli porusza kierownica, nie może być traktowany jako kierujący, gdyż nie ma dostępu do pedałów przyspieszenia, hamulca i nie dysponuje dostateczną widocznością. W związku z tym, w ocenie SN, za szkodę wyrządzoną omawianym zdarzeniem nie ponosi odpowiedzialności ani posiadacz pojazdu, ani kierujący nim, zatem wyłączona jest także odpowiedzialność zakładu ubezpieczeń.

Przytoczony wyrok został krytycznie oceniony przez Tomasza Justyńskiego. Zdaniem autora „kierujący” w rozumieniu art. 34 u.u.o. nie musi mieć pełnej kontroli nad pojazdem, lecz wystarczy, by miał rzeczywisty wpływ na ruch pojazdu ${ }^{33}$. Przedstawiciel piśmiennictwa zwraca uwagę na to, że odpowiedzialność cywilna kierującego została objęta obowiązkowym ubezpieczeniem komunikacyjnym OC ze względu na ochronę osób poszkodowanych. W związku z tym, zdaniem Justyńskiego, należy przyjąć, że pasażer, który szarpnałł za kierownicę powinien być uznany za kierującego w rozumieniu art. 34 u.u.o. ${ }^{34}$

Należy wskazać, że przywołany spór nie zaistniałby, gdyby zakresem obowiązkowego ubezpieczenia komunikacyjnego OC objąć także odpowiedzialność cywilna pasażera, jak wskazuje Trybunał Sprawiedliwości w wyroku w sprawie BTA Baltic Insurance. W takim przypadku nie trzeba byłoby dokonywać rozszerzającej wykładni pojęcia kierującego, aby zapewnić poszkodowanym zaspokojenie ich roszczeń przez zakład ubezpieczeń. Niekiedy taka bardzo szeroka interpretacja byłaby zupełnie niemożliwa do zastosowania. Można bowiem wyobrazić sobie następujące

32. Wyrok SN z 13 sierpnia 2008 r., sygn. I CSK 56/08, LEX nr 465369.

33. T. Justyński, Glosa do wyroku SN z 13 sierpnia 2008 r., sygn. I CSK 56/08, 0SP, nr 3/2010, s. 213.

34. Ibidem. 
zdarzenie - w wyniku sprzeczki jeden z pasażerów uderza kierującego samochodem, który traci kontrolę nad pojazdem i zjeżdża na przeciwległy pas, uderzając w samochód jadący z naprzeciwka. Taką sytuację należy zakwalifikować jako zderzenie dwóch mechanicznych środków komunikacji. W związku z tym posiadacze pojazdów odpowiadają względem siebie na zasadzie winy. W nakreślonym stanie faktycznym winę za doprowadzenie do wypadku ponosi jednak jedynie pasażer. W tym przypadku już nie jest możliwa rozszerzająca interpretacja pojęcia kierującego, proponowana przez Justyńskiego. Trudno bowiem uznać za kierującego pasażera, który nawet nie dotyka kierownicy. W takiej sytuacji poszkodowany posiadacz pojazdu, który jechał z naprzeciwka, nie mógłby uzyskać odszkodowania od zakładu ubezpieczeń w ramach obowiązkowego ubezpieczenia komunikacyjnego OC.

Podsumowując dotychczasowe uwagi, należy stwierdzić, że w przywołanych powyżej przykładach za wypadki drogowe odpowiedzialność cywilna ponosił wyłącznie pasażer samochodu. Są to bowiem sytuacje, w których odpowiedzialność posiadacza pojazdu kształtuje się na zasadzie winy, a nie ryzyka. Stąd niekiedy można przyjać, że w danym stanie faktycznym wyłącznie odpowiedzialnym za powstanie szkody jest pasażer. W takich sytuacjach, w myśl prawa polskiego, nie powstaje odpowiedzialność ubezpieczyciela z tytułu obowiązkowego ubezpieczenia OC posiadaczy pojazdów mechanicznych. Jak to już zostało wskazane, takie regulacje nie odpowiadaja wymaganiom, jakie sformułował TSUE w wyroku w sprawie BTA Baltic Insurance, który stwierdził, że obowiązkowe ubezpieczenie komunikacyjne OC powinno obejmować także odpowiedzialność cywilną pasażera. Wobec tego należy postulować zmianę art. 34 u.u.o., przez dodanie do katalogu ubezpieczonych, obok posiadacza i kierującego, także pasażera pojazdu. Dopóki nie dojdzie do postulowanej nowelizacji, poszkodowany, który będzie pozbawiany możliwości dochodzenia swoich roszczeń od zakładu ubezpieczeń z powodu braku ubezpieczenia odpowiedzialności cywilnej pasażera pojazdu, będzie mógł wystapić z żądaniem naprawienia szkody od Skarbu Państwa, z tytułu niewłaściwej implementacji dyrektywy Parlamentu Europejskiego i Rady 2009/103/WE ${ }^{35}$.

Komentowany wyrok TSUE należy ocenić pozytywnie. Rozszerzenie zakresu odpowiedzialności ubezpieczyciela w ramach obowiązkowego ubezpieczenia OC posiadaczy pojazdów mechanicznych na odpowiedzialność cywilna pasażera sprawi, że poszkodowani w wypadkach drogowych będa mieli zapewniona jeszcze pełniejszą ochronę niż dotychczas. Trzeba jednak pamiętać, że z wyłączną odpowiedzialnością pasażera pojazdu za szkody komunikacyjne będziemy mieli do czynienia relatywnie rzadko, co jest skutkiem bardzo szeroko określonego zakresu odpowiedzialności posiadacza mechanicznego środka komunikacji. Stąd też omawiane rozszerzenie zakresu odpowiedzialności ubezpieczyciela nie będzie miało znacznego rozmiaru.

\section{Podsumowanie}

Zgodnie z polskim ustawodawstwem obowiązkowe ubezpieczenie OC posiadaczy pojazdów mechanicznych obejmuje odpowiedzialność cywilną posiadacza pojazdu i kierującego. Pasażer nie jest zatem ubezpieczonym w ramach tego ubezpieczenia. Jednak za większość szkód komunikacyjnych wyrządzonych przez pasażera odpowiada zgodnie z przepisami prawa cywilnego posiadacz

35. J. Barcz, M. Górka, A. Wyrozumska, Instytucje i prawo Unii Europejskiego. Podręcznik dla kierunków prawa, zarzqdzania i administracji, Wolters Kluwer, Warszawa 2012, s. 314. 
pojazdu, stąd takie szkody będą kompensowane przez zakład ubezpieczeń. Istniejąjednak sytuacje, w których pasażer będzie wyłącznie odpowiedzialny za wypadek drogowy. Wówczas ubezpieczyciel nie będzie zobowiązany do wypłaty odszkodowania poszkodowanym. Takich wypadków dotyczy wyrok TSUE w sprawie BTA Baltic Insurance. Zgodnie z tym orzeczeniem odpowiedzialność cywilna pasażera powinna być objęta obowiązkowym ubezpieczeniem komunikacyjnym OC. Stąd należy postulować zmianę ustawy o ubezpieczeniach obowiązkowych polegającą na uznaniu pasażera za ubezpieczonego w ramach przedmiotowego ubezpieczenia. Taki zabieg spowoduje, że polskie prawo będzie spełniało wymogi określone przez TSUE, a nade wszystko zagwarantuje jeszcze większą ochronę poszkodowanym w wypadkach drogowych.

\section{Wykaz źródeł}

Barcz J., Górka M., Wyrozumska A., Instytucje i prawo Unii Europejskiego. Podręcznik dla kierunków prawa, zarzqdzania i administracji, Wolters Kluwer, Warszawa 2012.

Bieniek G., Odpowiedzialność cywilna za wypadki drogowe, Wolters Kluwer, Warszawa 2007.

Bucoń P., Odpowiedzialność cywilna uczestników wypadku komunikacyjnego, Wolters Kluwer, Warszawa 2008.

Byczko S., Prawo ubezpieczeń gospodarczych. Zarys wykładu, Difin, Warszawa 2013.

Justyński T., Glosa do wyroku SN z 13 sierpnia 2008 r., sygn. I CSK 56/08, 0SP 2010, nr 3.

Kodeks cywilny. Komentarz, Gniewek E., Machnikowski P. [red.], CH Beck, Warszawa 2019.

Kodeks cywilny. Komentarz LEX, Kidyba A. [red.], Warszawa 2014.

Kodeks cywilny. Komentarz. Tom III. Zobowiqzania. Część ogólna, Habdas M., Fras M. [red.], Wolters Kluwer, Warszawa 2018.

Kodeks cywilny. Tom II. Komentarz art. 353-626, Gutowski M. [red.], CH Beck, Warszawa 2019. Kodeks cywilny. Tom III. Zobowiqzania. Część ogólna, Gudowski J. [red.], Wolters Kluwer, Warszawa 2018.

Konieczna K., Granice pojęcia „ruchu pojazdów” w rozumieniu prawa Unii Europejskiej dotyczqcego obowiqzkowych ubezpieczeń komunikacyjnych - uwagi na tle orzeczenia Trybunału Sprawiedliwości w sprawie C-648/17 BTA Baltic Insurance Company, „Wiadomości Ubezpieczeniowe” 2018, nr 4.

Krajewski M., Ubezpieczenie odpowiedzialności cywilnej według kodeksu cywilnego, Wolters Kluwer, Warszawa 2011.

Lewaszkiewicz-Petrykowska B., Odpowiedzialność cywilna prowadzqcego na własny rachunek przedsiębiorstwo wprawiane w ruch za pomoca sił przyrody, Wydawnictwo Prawnicze, Łódź 1965.

Ludwichowska K., Odpowiedzialność cywilna i ubezpieczeniowa za wypadki samochodowe, TNOiK, Toruń 2008.

Miaskowski J., Niezgoda K., Skawiński P., Ustawa o ubezpieczeniach obowiqzkowych, Ubezpieczeniowym Funduszu Gwarancyjnym i Polskim Biurze Ubezpieczycieli Komunikacyjnych, CH Beck, Warszawa 2012.

Orlicki M., Pokrzywniak J., Raczyński A., Obowiqzkowe ubezpieczenie OC posiadaczy pojazdów mechanicznych, Oficyna Wydawnicza Branta, Bydgoszcz-Poznań 2007.

Prawo gospodarcze i handlowe, Katner W. J. [red.], Wolters Kluwer, Warszawa 2018.

Raczyński A., Sytuacja prawna poszkodowanego w ubezpieczeniu odpowiedzialności cywilnej, CH Beck, Warszawa 2010. 
Robaczyński W., Kontrowersje wokół pojęcia ruchu pojazdu (art. 436 K. C.), „Palestra” 2007, nr 5-6. System Prawa Prywatnego. Tom 6. Prawo zobowiqzań - część ogólna, Olejniczak A. [red.], CH

Beck, Warszawa 2014.

Szczechowicz J., Odpowiedzialność cywilna posiadacza mechanicznego środka komunikacji za szkody wyrzadzone w ruchu lqdowym, Pracownia Wydawnicza ElSet, Olsztyn 2013.

Wasiewicz A., Ubezpieczenia komunikacyjne, Oficyna Wydawnicza Branta, Bydgoszcz-Poznań 2001.

\section{The passenger as an insured person under the compulsory motor vehicle insurance - consequences of the judgement of European Court of Justice in case C-648/17 BTA Baltic Insurance Company}

The purpose of this article is to present the consequences of the judgement of European Court of Justice in case C-648/17 BTA Baltic Insurance Company. This verdict indicates that the compulsory motor vehicle insurance covers damage caused by the passenger of vehicle. However, in the light of Polish law, passenger is not recognized as an insured person under the compulsory motor vehicle insurance. As the consequences there are situations, when the insurer is not liable for damage caused by the passenger of vehicle. It is contrary to judgement of $\varepsilon C J$ in case C-648/1? BTA Baltic Insurance Company. Therefore, the Polish regulations on compulsory motor insurance should be amended to provide insurance protection also in situations, when damage is caused by the passenger of vehicle.

Keywords: use of vehicles, compulsory motor vehicle insurance, insured person, civil liability, compensation.

MGR JAKUB OLESZCZAK - absolwent Wydziału Prawa i Administracji Uniwersytetu Łódzkiego, aplikant aplikacji sędziowskiej

e-mail: jakub.oleszczak@gmail.com 